\title{
Studying the Reality of Institutional Excellence in Jordanian Government Sector: Opportunities and Challenges
}

\author{
Eng.Huda Saad Al Rashidi \\ Ministry of Transportation - State of Kuwait \\ Saoud R Al Rashidi \\ Ministry of Defense - State of Kuwait
}

Received: May 12, 2019 Accepted: May 30, 2019 Online published: June 4, 2019

doi:10.5296/ijhrs.v9i2.14770

URL: https://doi.org/10.5296/ijhrs.v9i2.14770

\begin{abstract}
The aim of this study is to assess the state of institutional excellence and the major opportunities and challenges facing it. In order to achieve the objectives of the study, the researcher used the descriptive approach and designed a questionnaire as a tool to study and distribute it to a sample of 30 decision makers from the directors and the heads of departments in three institutions of the Jordanian government sector. The main findings of the study are the following:

There were no statistically significant differences at the level of significance $(\alpha 0.05)$ in the impact of institutional excellence and its six dimensions (leadership, strategic planning, customer focus, measurement, analysis and knowledge management, focus on human resources and focus on internal processes) on improving institutional performance through the satisfaction of the recipients of services from citizens from the point of view of managers in Jordanian government institutions.

The main recommendations of the study were: the necessity of commitment and focus on excellence in strategic planning, which contributes to the development of solutions and alternatives that weaken the institutional performance and reduce the level of satisfaction of service recipients from citizens, and seek to maximize the basis of benefit gained on the principle of increased fees and evaluation through the development of flexible financial plans.
\end{abstract}


Keywords: institutional excellence, challenges, leadership, strategic planning, customer focus, measurement, analysis, knowledge management, focus on human resources, focus on internal processes

\section{Preface}

The recent years have witnessed a number of developments at the technical and scientific levels. This reflected positively on the institutional reality in all sectors. Therefore, this led the decision makers to seek for competitiveness and improvement within unusual levels of performance and application in the various forms of government institutions in Jordan. Through "Institutional Excellence."

Both Idris, Wael Mohsen (2009) point to the fact that many government leaders and decision makers are seeking to adopt the latest tools in order to keep up with the pace of change and the highly competitive pressure between institutions to achieve the scale. The Learning Organization model was therefore an important mechanism to help them adapt more effectively to improvement with excellence in government service provision.

In other words, institutional excellence represents the pursuit of opportunities by enterprises to take advantage of opportunities, preceded by effective strategic planning, with a commitment to a common vision that is clear in objective, resource efficient and improving performance at its highest level (Ayyubi, 2015).

In addition to the above, institutional excellence is one of the most important and latest issues which the institutions seek to highlight in order to support more differentiation and uniqueness in their levels of performance which drives the administrative bodies to make more efforts to reach the stage of success and overcome them by relying on speed, Flexibility and innovation (Hijazi, 2016).

In order to improve and develop the institutional performance of the service level of the homeland, citizens and investors in all government departments and institutions in the Hashemite Kingdom of Jordan and to raise awareness among the employees of this sector and competitiveness and highlight the institutional excellence among them. The Royal Decree issued on 4/9/2002, Abdullah II Award for Excellence in Government Performance and Transparency "to be the highest award in its local level (Al-Dajah, 2016).

\section{The Study Statement}

Barkhuizen, E. \& Schutte, N. (2014) refers to three basic dimensions for improving institutional performance, as determined by the King Abdullah II Award for excellence in (internal processes, learning and growth, and satisfaction of service recipients). This award seeks to achieve national goals at all levels and to optimize the capabilities of its employees. The problem of the current study is to study the reality of institutional excellence in the institutions of the Jordanian government sector and to identify the most important opportunities and challenges facing these units towards achieving excellence. The problem of this study can be summed up in answering the following questions: 


\section{Macrothink}

International Journal of Human Resource Studies

ISSN 2162-3058 2019, Vol. 9, No. 2

2.1 What is the reality of institutional excellence in the institutions of the Jordanian government sector from the point of view of decision makers?

2.2 What are the challenges and opportunities facing these institutions in achieving institutional excellence during their work?

2.3 What are the appropriate criteria for assessing institutional performance from the point of view of their managers?

\section{The Study Importance}

This study seeks to identify the reality of institutional excellence in the Jordanian government sector through:

3.1 Studying the state of excellence in the Jordanian government institutions from the point of view of decision makers.

3.2 Studying the opportunities and challenges facing Jordanian government institutions in achieving excellence.

3.3 Determine the best standards used to measure the extent of excellence in the institutions of the Jordanian government sector from the point of view of decision makers.

\section{Study Objectives}

The study aims at analyzing the reality of institutional excellence in the Jordanian government sector through conducting a field study. It also aims at empowering the participants in the King Abdullah II Excellence Award to deal with the rapid developments and changes that are facing them during their work. The current study aims at enriching the theoretical studies in management through a study that has a new orientation different from the previous one, which helps the administrative decision makers at the level of the governmental sector, which constitutes the largest sector in the Kingdom.

\section{Study Model}

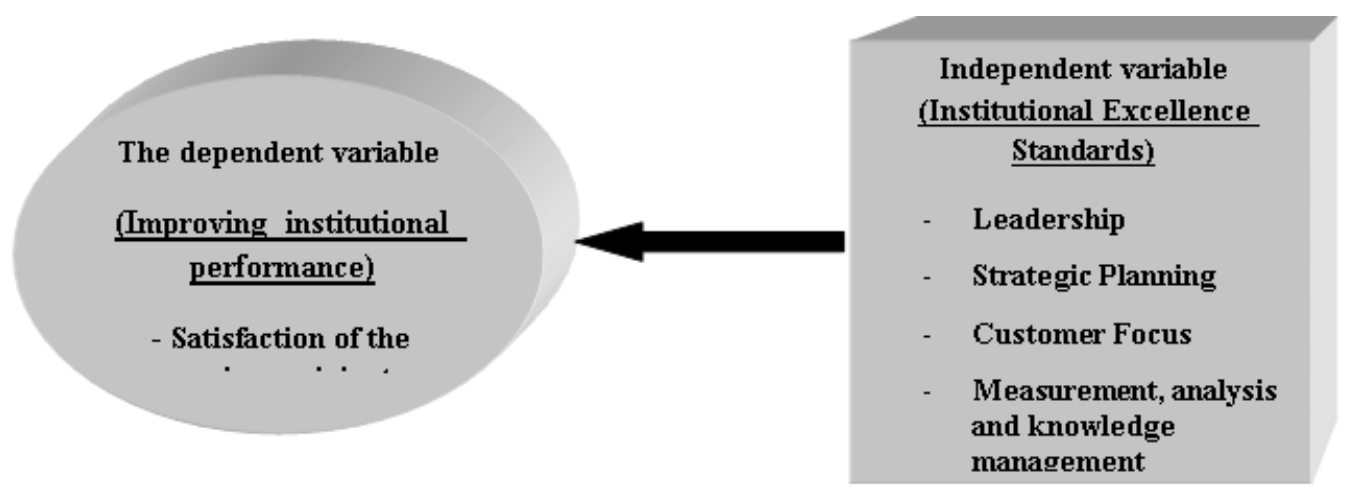

Figure 1. Represents a model for the current study

By the researcher based on the study of Qawasmeh (2016); Buqais. E. (2018); and Dajah, (2016). 


\section{Study Hypotheses}

The main hypothesis of the study (HO1): There are no statistically significant differences at the level of $(\alpha 0.05)$ in the impact of the standards of institutional excellence on the improvement of institutional performance from the point of view of managers in the institutions of the Jordanian government sector.This main premise is based on the following sub-assumptions:

HO1: There were no statistically significant differences at the level of significanc $(\alpha \leq 0.05)$ in the effect of leadership on satisfaction of service recipients from the point of view of managers in the Jordanian government sector institutions.

HO1: There are no statistically significant differences at the level of significance $(\alpha \leq 0.05)$ in the effect of strategic planning on satisfaction of service recipients from the point of view of managers in the Jordanian government sector institutions.

HO1: There were no statistically significant differences at the level of $(\alpha \leq 0.05)$ in the effect of customer focus on satisfaction of service recipients from the point of view of managers in Jordanian government institutions.

HO1: There were no statistically significant differences at the level of significanc $(\alpha \leq 0.05)$ in the effect of measurement, analysis and knowledge management on the satisfaction of the recipients of the service from the point of view of managers in the institutions of the Jordanian government sector.

HO1: There were no statistically significant differences $(\alpha \leq 0.05)$ in the impact of the emphasis on human resources on the satisfaction of the recipients of the service from the point of view of managers in the institutions of the Jordanian government sector.

HO1: There were no statistically significant differences at the level of significanc $(\alpha \leq 0.05)$ in the effect of the emphasis on the operations on the satisfaction of the recipients of the service from the point of view of managers in the institutions of the Jordanian government sector.

\section{Theoretical Framework}

\subsection{Institutional Excellence}

\subsubsection{The Concept of Institutional Excellence}

Hijazi (2016) defined organizational excellence as "a state of excellence in providing all services efficiently and efficiently through the adoption of mechanisms to ensure continuous progress in all aspects and at all levels, and work to maintain this excellence by keeping pace with developments on an ongoing basis." Al nswr (2010) defined it as "the organization's endeavor to take advantage of the critical opportunities ahead of effective strategic planning and commitment to realize the common vision that is dominated by clarity of purpose, adequacy of sources and keenness on performance". 
7.1.2 The Importance of Institutional Excellence

Al sudi (2008) highlighted the importance of institutional excellence in terms of:

A. Means of bringing information so that the institution can make decisions;

B. Means to identify the obstacles they face if they arise;

C. Provide indicators and skills for decision-makers with a focus on human resources;

D. A tool to develop the skills of employees at all levels of the job.

\subsubsection{Characteristics of Institutional Excellence}

Sahli (2016) summarizes the characteristics of the organization with institutional excellence as follows:

- Ability to face difficulties: The difficulties show the ability of the institution to grow, learn and compete.

- Provide efficient leadership: Leadership and management represent an example of human resources in the institution.

- The ability to acquire expertise away from work: where the organizations are distinguished by the skills of external experts with expertise in the field of work.

- Ability to develop skills and training programs: The key criterion of excellence is human competencies.

- Accuracy in work: strengthening the system of predicting and avoiding errors in the organization.

\subsubsection{Standards of Institutional Excellence}

Both Qawasmeh and Al Burini (2016) set the criteria for institutional performance excellence as follows:

- Leadership: the ability to influence the behavior of others and guide them for the better.

- Strategic planning: the integrated process of identifying the interests of the organization in the external environment, focusing on obtaining information about the past and present, and predicting the level of performance.

- Focus on customers: Highlighting the needs of customers and making use of them in identifying institutional priorities.

- Measurement, analysis and knowledge management: by measuring and analyzing the level of institutional excellence in the department and providing all employees with sufficient information about this level. 
- Focus on human resources: The human element is the most important elements in the institution as it represents the main engine of its work, focusing on the desires and incentives of human resources contribute to raising the level of activity.

- Focus on operations: The focus on high level of performance in the completion of the process and stages contribute to the level of service provided to the recipients of the service from the external audience.

\subsection{Improving institutional performance}

\subsubsection{The Concept of Improving Institutional Performance}

It can be said that institutional performance represents the integrated system of the results of the work of the organization or the department in the light of its interaction with the public internal and external. It can be said that institutional excellence in the Jordanian government sector based on the King Abdullah II Award for Excellence is based on three basic elements:

A. Excellence in the performance of individuals in their organizational units or "excellence in employee performance;"

B. The performance of the organizational unit within the framework of the institution's overall policies or "excellence in the performance of the organization;"

C. The performance of the organization as a whole within the surrounding environment or "excellence in the performance of the department."

\subsubsection{Dimensions of Improving Institutional Performance}

Kaplan and Norton (1992) identified the basic dimensions of improving institutional performance from their point of view in the Balance Score Card, which the researcher considers applicable to Jordanian government institutions as follows:

- Satisfaction of the recipient of the service: highlights the issues related to feedback and the opinion of the recipient of the service from citizens about government services, whether direct or indirect.

- Internal processes: This dimension relates to the processes used to provide services to customers (external audience of service recipients), and the level of service efficiency provided to them, taking into account the critical operations and emergencies and how to improve them.

- Learning and growth: This dimension focuses on the providers of government services and how to do so, since it is not possible to provide high quality services without the presence of individuals motivated by the tasks and the availability of tools and capabilities necessary to achieve these goals. 
7.2.3 Standards for Measuring Institutional Performance

Corporate performance measures refer to the rates at which the organization can guide them as a basis for evaluation and review by comparing strategic performance to actual performance by taking three criteria into consideration (Idris and Galby, 2009):

A. Quality in performance (quality): refers to the level of performance in all activities of the institution.

B. The amount of work performed (quantity): The volume of work performed and in this measure must not exceed the services provided capabilities of the employees of this institution and not less, because this negatively affects the speed of completion.

C. Procedures: represent the stages of the work progress in the institution, which is an anticipatory statement of the procedures, and steps that will be implemented, the methods used and the methods required.

\subsection{Excellence in Institutional Performance in the Jordanian Government Sector}

The results of the King Abdullah II Award for Government Excellence for 2018 indicate that the analytical results indicated an improvement in the level of excellence of government performance and transparency in the eighth cycle, an increase of (1.8\%) from the previous session.

The results of the field visits show an improvement of (7.6\%) according to the criteria used in the evaluation process, improvement by (4.8\%) on satisfaction of the service recipient, and a decrease of (17.2\%) from the results of "hidden shopper" or surprise inspection, where none of the institutions participating in the award reached the level of effectiveness in performance and win the Golden Award.

In addition, the results of the last session indicate that none of the participating government institutions showed the developmental trend of development of the governmental administration. The results ratios were stable at $1 \%$ of the total improvement. The field visit rate reached a limit of (300/1000) this is due to the lack of interest of previous administrations and governments in general in supporting excellence, development and improvement with due attention.

As for the Secretary-General Award, the results showed a wide variation among the institutions due to the change in this leadership category, which led to the participation of (32) people from this category of leading governmental institutions out of 104 institutions and departments. The researcher summarizes the participation in the King Abdullah II Award for Excellence in Performance for the last session in Table: (1) 


\section{Macrothink}

International Journal of Human Resource Studies

ISSN 2162-3058

2019, Vol. 9, No. 2

Table (1). Summary of the results of the King Abdullah II Award for Government Excellence - Eighth Session

\begin{tabular}{l|l}
\hline Category & Participants Number \\
\hline Sectors & 10 \\
\hline Institutions and government ministries & 104 \\
\hline Government employees outstanding applicants & 343 \\
\hline Government employees outstanding candidates & 27 \\
\hline Government employees outstanding winners & 16 \\
\hline Institutions and private companies applicants & 49 \\
\hline Private institutions and companies candidates & 27 \\
\hline Institutions and private companies Shielded by award & 22 \\
\hline
\end{tabular}

*Prepared by the researcher, based on the report of King Abdullah Center for Government Excellence 2018.

\section{Research Methodology}

The researcher seeks to adopt the "A Descriptive Survey Approach", based on both the theoretical framework and the applied approach in this study. The methods used in this approach can be summarized and summarized as follows (Al Osman, 2008):

Society and Study Sample

The study community is composed of all decision makers (managers) working in the Jordanian government sector. For the purposes of the study, a sample of (30) managers was established in the institutions to which the study limits apply. The researcher identified the field of application as follows:

- General Organization for Social Security: (10) directors or heads of departments;

- General Customs Department: (10) directors or heads of departments;

- Ministry of Industry and Trade: (10) managers or heads of departments.

\subsection{Study Tool}

The questionnaire was designed as a tool for study through the survey of scientific studies related to the study area and the dimensions of the variables to form the total of the items for the questionnaire, and then was arbitrated by a group of experts in this field, and then distributed by 30 copies to a sample of managers or Heads of departments in the institutions of the Jordanian government sector, where they retrieved the valid questionnaires to use in determining the results of the current study.

\section{Results}

The results of the response of the target group of the study sample for the study tool (questionnaire) are analyzed here. They were analyzed using the SPSS software, as follows: 


\subsection{Descriptive Statistics of the Sample of the Study Sample}

The tables of figures (2-7) show the demographic variables of the sample of the study (functional category, sex, scientific qualification, nature of work, number of years of experience)

Table (2). Distribution of Study Sample Members by Functional Category

\begin{tabular}{l|l|l}
\hline Functional category & Repetition & Perecentage \\
\hline First & 22 & 73.3 \\
\hline Second & 4 & 13.3 \\
\hline Third & 3 & 10.0 \\
\hline Comprehensive contract & 1 & 3.3 \\
\hline Total & $\mathbf{3 0}$ & $\mathbf{1 0 0 . 0}$ \\
\hline
\end{tabular}

Table (2) shows that the number of the first group in the study sample is (22) ie (73.3\%), that the number of the second group in the study sample (4) is $13.3 \%(10.0 \%)$, while the number of employees of comprehensive contracts in the study (1) by (3.3\%)

Table (3). Distribution of the sample of the study by gender

\begin{tabular}{l|l|l}
\hline Gender & Repetition & Perecentage \\
\hline Male & 14 & $\mathbf{4 6 . 7}$ \\
\hline Female & 16 & $\mathbf{5 3 . 3}$ \\
\hline Total & $\mathbf{3 0}$ & $\mathbf{1 0 0 . 0}$ \\
\hline
\end{tabular}

Table (3) shows that the number of males in the sample of the study reached (14) employees by $(46.7 \%)$, while the number of females (16) employee by $(53.3 \%)$.

Table (4). Distribution of Study Sample Members by Academic Qualification

\begin{tabular}{l|l|l}
\hline Academic Qualification & Repetition & Percentage \\
\hline M.A. & 4 & 13.3 \\
\hline BA & 20 & 66.7 \\
\hline Diploma & 4 & 13.3 \\
\hline Secondary or below & 2 & 6.7 \\
\hline Total & $\mathbf{3 0}$ & $\mathbf{1 0 0 . 0}$
\end{tabular}

The number of holders of the Master's degree has reached (4) by (13.3\%), while the number of BA holders was (20) and (66.7\%). while secondary or below (2\%) were employed $(6.7 \%)$ 
Table (5). Distribution of the sample of the study according to the nature of the work

\begin{tabular}{ll|l|lr}
\hline & Work Nature & \multicolumn{1}{c}{ Repetition } & \multicolumn{2}{r}{ Percentage } \\
\hline \multicolumn{1}{r|}{ Financial Jobs } & & 8 & \\
\hline Technical Jobs & 10 & $\mathbf{3 3 . 3}$ & $\mathbf{4 6 . 7}$ \\
\hline Supervisory jobs & 12 & $\mathbf{4 0 . 0}$ & \\
\hline Total & $\mathbf{3 0}$ & $\mathbf{1 0 0 . 0}$ & \\
\hline
\end{tabular}

Table (5) shows that the number of employees in financial jobs is (8) individuals by $(26.7 \%)$, while the number of employees in technical jobs (10) individuals by $(33.3 \%), 12)$ by $40.0 \%$. while the number of employees in supervising posts was $12(40.0 \%)$.

Table (6). Distribution of Study Sample Individuals by Years of Experience

\begin{tabular}{l|l|l}
\hline Years of Experience & Repetition & Percentage \\
\hline $1-5$ years & 12 & 40.0 \\
\hline More than 5 years & 18 & 60.0 \\
\hline Total & 30 & 100.0 \\
\hline
\end{tabular}

Table (6) shows that the number of years of experience in category (1-5) reached (12) individuals by $(40.0 \%)$, while the number of years of experience in category ( 5 years and above) was (18).

\subsection{The Results of the Test Questions and Hypotheses of the Study}

a. Calculation coefficient of internal consistency (Kronbach alpha)

Table (7). Coefficient of internal consistency

\begin{tabular}{|c|c|c|}
\hline The field & Pargraphs number & The value of (a) alpha \\
\hline \multicolumn{3}{|c|}{ Standards of Institutional Excellence } \\
\hline $\begin{array}{l}\text { Standard of Excellence in } \\
\text { Leadership }\end{array}$ & 3 & 90.2 \\
\hline $\begin{array}{l}\text { Standard of Excellence in Strategic } \\
\text { Planning }\end{array}$ & 3 & 92.3 \\
\hline $\begin{array}{l}\text { Standard of Excellence in } \\
\text { Customer Focus }\end{array}$ & 3 & 79.9 \\
\hline $\begin{array}{llr}\text { Standard of } & \text { Excellence } & \text { in } \\
\text { Measurement, } & \text { Analysis and } \\
\text { Knowledge Management }\end{array}$ & 3 & 87.8 \\
\hline $\begin{array}{l}\text { Standard of excellence in } \\
\text { focusing on human resources }\end{array}$ & 3 & 87.1 \\
\hline $\begin{array}{l}\text { Standard of Excellence in Focus } \\
\text { on Processes }\end{array}$ & 3 & 93.1 \\
\hline $\begin{array}{l}\text { Improve performance by achieving } \\
\text { customer satisfaction }\end{array}$ & 7 & 87.2 \\
\hline
\end{tabular}

It is clear from Table (7) that the field consistency coefficient has a high degree of stability, 
with stability levels ranging from (93.7-79.9).

\subsubsection{Results Analysis of the Study Questions}

The main question of the study: "What is the reality of institutional excellence in the institutions of the Jordanian government sector from the point of view of decision makers?"

To answer this question, the arithmetical averages and standard deviations of each of the criteria for the reality of institutional excellence in government sector institutions were calculated from the point of view of decision makers.

Table (8) shows that the averages for the areas of the criteria of the reality of institutional excellence in the institutions of the public sector from the point of view of the decision-makers are in descending order. It was high, ranging from (4.23-3.90) to a high level. (4.23) with a high level, followed by the Excellence in Leadership (4.22) and a high level, while the Excellence in Strategic Planning ranked last with an average (3.90) and a high level.

Table (8). The arithmetical averages and the standard deviations of each criterion of the reality of institutional excellence in the institutions of the public sector from the point of view of the decision makers in descending order

\begin{tabular}{|c|c|c|c|c|}
\hline Rank & Standards & $\begin{array}{c}\text { Arithmetical } \\
\text { average }\end{array}$ & $\begin{array}{r}\text { Standard } \\
\text { deviation }\end{array}$ & Level \\
\hline 1 & $\begin{array}{ll}\text { Standard } & \text { of } \\
\text { Excellence } & \text { in } \\
\text { Customer Focus } & \end{array}$ & 4.23 & .526 & High \\
\hline 2 & $\begin{array}{ll}\text { Standard } & \text { of } \\
\text { Excellence } & \text { in } \\
\text { Leadership } & \\
\end{array}$ & 4.22 & .697 & High \\
\hline 3 & $\begin{array}{ll}\text { Standard } & \text { of } \\
\text { Excellence } & \text { in } \\
\text { Measurement, } & \\
\text { Analysis } & \text { and } \\
\text { Knowledge } & \\
\text { Management } & \\
\end{array}$ & 4.06 & .626 & High \\
\hline 4 & $\begin{array}{l}\text { Excellence in } \\
\text { focusing on human } \\
\text { resources }\end{array}$ & 3.99 & .616 & High \\
\hline 5 & $\begin{array}{l}\text { Standard of } \\
\text { Excellence in Focus } \\
\text { on Processes }\end{array}$ & 3.91 & .705 & High \\
\hline 6 & $\begin{array}{l}\text { Excellence in } \\
\text { strategic planning }\end{array}$ & 3.90 & .744 & High \\
\hline \multicolumn{2}{|r|}{ Total score $=$} & .528 & 4.05 & High \\
\hline
\end{tabular}


C - Analysis of the results of the hypotheses of the study

The main hypothesis of the study: To test this hypothesis, Simple Regression was used because this hypothesis looks at the effect of all the dimensions of the independent variable combined on one dependent variable, namely the improvement of institutional performance. The results of this hypothesis were presented in Table 9.

Table (9) shows the impact of institutional excellence standards on improving institutional performance from the point of view of managers in Jordanian government institutions. The results of the statistical analysis showed that there is a statistically significant effect of the standards of institutional excellence on the improvement of institutional performance from the point of view of managers in Jordanian government institutions. The correlation coefficient $\mathrm{R}(0.479)$ was at the level of $\alpha(0.05)$. The $\mathrm{R} 2$ coefficient was 0.230 , ie, the criteria for institutional excellence explained $23 \%$ of the changes in institutional performance from the point of view of managers in the Jordanian government institutions. The value of the effect was $\beta(0.559)$ the increase of one degree in the standards of institutional excellence leads to further

Table (9). A simple regression analysis to determine the impact of institutional excellence standards on improving institutional performance from the point of view of managers in the Jordanian government sector institutions

\begin{tabular}{l|l|l|l|l|l|l|l|l|l}
\hline $\begin{array}{l}\text { Independent } \\
\text { variable }\end{array}$ & $\begin{array}{l}\text { Linking } \\
\mathbf{R}\end{array}$ & $\begin{array}{l}\text { Selection } \\
\text { Factor } \\
\mathbf{R}^{2}\end{array}$ & $\mathbf{F}$ & $\begin{array}{l}\text { Sig* } \\
\mathbf{F}\end{array}$ & $\begin{array}{l}\text { Gradient } \\
\text { coefficient } \\
\boldsymbol{\beta}\end{array}$ & $\mathbf{T}$ & $\begin{array}{l}\text { Level of } \\
\text { significance } \\
\text { Sig.*t }\end{array}$ & $\begin{array}{l}\text { Fixed } \\
\text { limit }\end{array}$ & $\begin{array}{l}\text { Hypothesis } \\
\text { Result }\end{array}$ \\
\hline $\begin{array}{l}\text { Standards of } \\
\text { Institutional } \\
\text { Excellence }\end{array}$ & .479 & .230 & 8.345 & .007 & .559 & 2.889 & .007 & 1.778 & Refusal \\
\hline
\end{tabular}

Improvement of institutional performance from the point of view of managers in the institutions of the Jordanian government sector (0.559). The significance of this effect is the value of F, which reached (8.345) Acceptance of the zero hypothesis which states: "There are no significant differences in the standards of institutional excellence to improve performance Pesce from the point of managers in the Jordanian public sector institutions looked at the significance level (0.05).

The first sub-hypothesis of the study: To test this hypothesis, Simple Regression analysis was used because this hypothesis examines the effect of leadership on improving institutional performance. The results of testing this hypothesis are shown in Table 17: 
Table (10). A simple regression analysis to determine the impact of leadership on improving institutional performance from the point of view of managers in Jordanian government institutions

\begin{tabular}{l|l|l|l|l|l|l|l|l|l}
\hline $\begin{array}{l}\text { Independent } \\
\text { variable }\end{array}$ & $\begin{array}{l}\text { Linking } \\
\mathbf{R}\end{array}$ & $\begin{array}{l}\text { Selection } \\
\text { Factor } \\
\mathbf{R}^{2}\end{array}$ & $\mathbf{F}$ & $\begin{array}{l}\text { Sig* } \\
\mathbf{F}\end{array}$ & $\begin{array}{l}\text { Gradient } \\
\text { coefficient } \\
\boldsymbol{\beta}\end{array}$ & $\mathbf{T}$ & $\begin{array}{l}\text { Level of } \\
\text { significance } \\
\text { Sig.*t }\end{array}$ & $\begin{array}{l}\text { Fixed } \\
\text { limit }\end{array}$ & $\begin{array}{l}\text { Hypothesis } \\
\text { Result }\end{array}$ \\
\hline Leadership & .383 & .147 & 4.812 & .037 & .338 & 2.194 & .037 & 2.614 & Refusal \\
\hline
\end{tabular}

Table (10) shows the impact of leadership on improving institutional performance from the point of view of managers in Jordanian government institutions. The results of the statistical analysis showed a statistically significant effect of the leadership on improving the institutional performance from the point of view of managers in the Jordanian government institutions. The correlation coefficient $\mathrm{R}(0.383)$ was at the level of significance $(\alpha 0.05)$. The coefficient of determination of R2 was 0.147 . In other words, the leadership explained $14.7 \%$ of the changes in the institutional performance from the point of view of the managers in the Jordanian government institutions. The value of the effect was $\beta(0.338)(0.338)$. The significance of this effect is the value of F (4.812), which is a function at the level of significance $(\alpha 00.05)$. This confirms the validity of acceptance of the zero hypothesis and that "There are no significant differences of leadership in improving institutional performance from the point of view of managers in the sector Jordanian government at the significance level (0.05)

The second sub-hypothesis of the study:

To test this hypothesis, Simple Regression analysis was used because this hypothesis examines the impact of strategic planning on improving institutional performance. The results of this hypothesis were presented in Table 11:

Table (11). A simple regression analysis to determine the impact of strategic planning on improving institutional performance from the point of view of managers in Jordanian government institutions

\begin{tabular}{l|c|c|c|c|c|c|c|c|c}
\hline $\begin{array}{c}\text { Independent } \\
\text { variable }\end{array}$ & $\begin{array}{c}\text { Linking } \\
\mathbf{R}\end{array}$ & $\begin{array}{c}\text { Selection } \\
\text { Factor } \\
\mathbf{R}^{2}\end{array}$ & $\mathbf{F}$ & $\begin{array}{c}\text { Sig* } \\
\mathbf{F}\end{array}$ & $\begin{array}{c}\text { Gradient } \\
\text { coefficient } \\
\boldsymbol{\beta}\end{array}$ & $\mathbf{T}$ & $\begin{array}{c}\text { Level of } \\
\text { significance } \\
\text { Sig.*t }\end{array}$ & $\begin{array}{c}\text { Fixed } \\
\text { limit }\end{array}$ & $\begin{array}{c}\text { Hypothesis } \\
\text { Result }\end{array}$ \\
\hline $\begin{array}{l}\text { Strategic } \\
\text { planning }\end{array}$ & .437 & .191 & 6.59 & .016 & .361 & 2.56 & .016 & 2.633 & Refusal \\
\hline
\end{tabular}

Table (18) shows the impact of strategic planning on improving institutional performance from

the point of view of managers in Jordanian government sector institutions. The results of the 
statistical analysis showed a statistically significant effect of strategic planning on improving institutional performance from the point of view of managers in the Jordanian government institutions. The correlation coefficient $\mathrm{R}(0.437)$ was at the level of $(\alpha 0.05)$. The coefficient of determination of R2 was 0.191 , ie, strategic planning explained $19.1 \%$ of the changes in institutional performance from the point of view of managers in the Jordanian government institutions. The value of the effect was $\beta(0.361)$. This means that the increase with a score of (0.361). The significance of this effect is the value of $F(6.59)$, which is a function at the level of significance $(\alpha 00.05)$. This confirms the validity of acceptance of the hypothesis which states: "There are no significant differences of strategic planning on improving institutional performance from the point of view of managers in the institutions of the Jordanian government sector at the level of significance (0.05)

The third sub-hypothesis of the study: To test this hypothesis, Simple Regression was used because this hypothesis examines the effect of customer focus on improving institutional performance. The results of this hypothesis test were shown in Table 12:

Table (12). A simple regression analysis to determine the impact of customer focus on improving institutional performance from the point of view of managers in Jordanian government institutions

\begin{tabular}{l|l|l|l|l|l|l|l|l|l}
\hline $\begin{array}{l}\text { Independent } \\
\text { variable }\end{array}$ & $\begin{array}{l}\text { Linking } \\
\mathbf{R}\end{array}$ & $\begin{array}{l}\text { Selection } \\
\text { Factor } \\
\mathbf{R}^{2}\end{array}$ & $\mathbf{F}$ & $\begin{array}{l}\text { Sig* } \\
\mathbf{F}\end{array}$ & $\begin{array}{l}\text { Gradient } \\
\text { coefficient } \\
\boldsymbol{\beta}\end{array}$ & $\mathbf{T}$ & $\begin{array}{l}\text { Level of } \\
\text { significance } \\
\text { Sig.*t }\end{array}$ & $\begin{array}{l}\text { Fixed } \\
\text { limit }\end{array}$ & $\begin{array}{l}\text { Hypothesis } \\
\text { Result }\end{array}$ \\
\hline $\begin{array}{l}\text { Focus on } \\
\text { customers }\end{array}$ & .384 & .147 & 4.835 & .036 & .449 & 2.199 & .036 & 2.143 & Refusal \\
\hline
\end{tabular}

Table (12) shows the impact of customer focus on improving institutional performance from the point of view of managers in Jordanian government institutions. The results of the statistical analysis showed a statistically significant effect of customer focus on improving institutional performance from the point of view of managers in Jordanian government institutions. The correlation coefficient $\mathrm{R}(0.384)$ was at the level of $\alpha(0.05)$. The $\mathrm{R}^{2}$ concentration factor was 0.147 . In other words, the focus on customers accounted for $14.7 \%$ of the changes in institutional performance from the point of view of managers in the Jordanian government sector institutions. The value of the effect was $\beta(0.449)$ The increase of one degree in customer focus leads to further improvement of institutional performance from the point of view of managers in the Jordanian government institutions at (0.068). The significance of this effect is the value of $F$ which reached (4.835) Acceptance of the zero hypothesis, which states: "There are no statistically significant differences to focus on customers to improve performance For the founders from the point of view of managers in the institutions of the Jordanian government sector at the level of significance (0.05)" .

The fourth sub-hypothesis of the study: To test this hypothesis, Simple Regression was used because this hypothesis examines the effect of measurement, analysis and knowledge 
management on improving institutional performance. The results of this hypothesis were presented in Table 13:

Table (13). A simple regression analysis to determine the impact of measurement, analysis and knowledge management on the improvement of institutional performance from the point of view of managers in Jordanian government institutions

\begin{tabular}{l|c|c|c|c|c|c|c|c|c}
\hline $\begin{array}{c}\text { Independent } \\
\text { variable }\end{array}$ & $\begin{array}{c}\text { Linking } \\
\mathbf{R}\end{array}$ & $\begin{array}{c}\text { Selection } \\
\text { Factor } \\
\mathbf{R}^{2}\end{array}$ & $\mathbf{F}$ & $\begin{array}{c}\text { Sig* } \\
\mathbf{F}\end{array}$ & $\begin{array}{c}\text { Gradient } \\
\text { coefficient } \\
\boldsymbol{\beta}\end{array}$ & $\mathbf{T}$ & $\begin{array}{c}\text { Level of } \\
\text { significance } \\
\text { Sig.*t }\end{array}$ & $\begin{array}{c}\text { Fixed } \\
\text { limit }\end{array}$ & $\begin{array}{c}\text { Hypothesis } \\
\text { Result }\end{array}$ \\
\hline $\begin{array}{l}\text { Measurement, } \\
\text { analysis and } \\
\text { knowledge } \\
\text { management }\end{array}$ & .394 & .156 & 5.159 & .031 & .388 & 2.27 & .031 & 2.469 & Refusal \\
\hline
\end{tabular}

Table (13) shows the impact of measurement, analysis and knowledge management on improving institutional performance from the point of view of managers in Jordanian government sector institutions. The results of the statistical analysis showed a statistically significant impact of the measurement, analysis and knowledge management on the improvement of the institutional performance from (15.6\%) of the changes in the institutional performance from the point of view of managers in the institutions of the Jordanian government sector. Means that the increase of one degree in measurement, analysis and knowledge management leads to further improvement of institutional performance from the point of view of managers in the institutions of the Jordanian government sector $(0.388)$. The significance of this effect is the value of F, which reached (5.159) this confirms the validity of the acceptance of the null hypothesis, which states: "None Galleries meaningful measurement, analysis and knowledge management to improve corporate performance from the point of managers in the Jordanian public sector institutions looked at the significance level (0.05).

The fifth sub-hypothesis of the study: To test this hypothesis, Simple Regression was used because this hypothesis examines the impact of the focus on human resources on improving institutional performance. The results of this hypothesis were presented in Table 14:

Table (14) shows the impact of the focus on human resources on improving institutional performance from the point of view of managers in Jordanian government institutions. The results of the statistical analysis showed that there was a statistically significant effect of the emphasis on human resources on improving the institutional performance from the point of view of the managers in the Jordanian government institutions. The correlation coefficient $\mathrm{R}$ $(0.417)$ was at the level of $(\alpha 0.05)$. The $\mathrm{R} 2$ concentration factor was 0.174 . In other words, the focus on human resources accounted for $(17.4 \%)$ of the changes in institutional performance from the 


\section{Mll Macrothink}

International Journal of Human Resource Studies

ISSN 2162-3058

2019, Vol. 9, No. 2

Table (14). A simple regression analysis to determine the impact of the focus on human resources on improving institutional performance from the point of view of managers in Jordanian government institutions

\begin{tabular}{l|c|c|c|c|c|c|c|c|c}
\hline $\begin{array}{c}\text { Independent } \\
\text { variable }\end{array}$ & $\begin{array}{c}\text { Linking } \\
\mathbf{R}\end{array}$ & $\begin{array}{c}\text { Selection } \\
\text { Factor } \\
\mathbf{R}^{2}\end{array}$ & $\mathbf{F}$ & $\begin{array}{c}\text { Sig* } \\
\mathbf{F}\end{array}$ & $\begin{array}{c}\text { Gradient } \\
\text { coefficient } \\
\boldsymbol{\beta}\end{array}$ & $\mathbf{T}$ & $\begin{array}{c}\text { Level of } \\
\text { significance } \\
\text { Sig.*t }\end{array}$ & $\begin{array}{c}\text { Fixed } \\
\text { limit }\end{array}$ & $\begin{array}{c}\text { Hypothesis } \\
\text { Result }\end{array}$ \\
\hline $\begin{array}{l}\text { Focus on } \\
\text { Human } \\
\text { Resources }\end{array}$ & .417 & .174 & 5.901 & .022 & .417 & 2.42 & .022 & 2.379 & Refusal \\
\hline
\end{tabular}

point of view of managers in the Jordanian government institutions. The value of the effect was $\beta(0.417)$ The increase of one degree in the focus on human resources leads to further improvement of institutional performance from the point of view of managers in the institutions of the Jordanian government sector (0.417). The significance of this effect is the value of $F$, which reached (5.901), a function at the level of significance $(\alpha 0.05)$ Confirms the validity of the acceptance of the zero hypothesis which states: "There are no significant differences to focus on human resources To improve the institutional performance from the point of view of managers in the Jordanian government institutions at the level of significance (0.05).

The sixth sub-hypothesis of the study: To test this hypothesis, Simple Regression was used because this hypothesis examines the effect of the emphasis on processes on improving institutional performance. The results of this hypothesis were presented in Table 15:

Table (15). A simple regression analysis to determine the effect of the emphasis on operations on improving institutional performance from the point of view of managers in Jordanian government institutions

\begin{tabular}{l|c|c|c|c|c|c|c|c|c}
\hline $\begin{array}{c}\text { Independent } \\
\text { variable }\end{array}$ & $\begin{array}{c}\text { Linking } \\
\mathbf{R}\end{array}$ & $\begin{array}{c}\text { Selection } \\
\text { Factor } \\
\mathbf{R}^{2}\end{array}$ & $\mathbf{F}$ & $\begin{array}{c}\text { Sig* } \\
\mathbf{F}\end{array}$ & $\begin{array}{c}\text { Gradient } \\
\text { coefficient } \\
\boldsymbol{\beta}\end{array}$ & $\mathbf{T}$ & $\begin{array}{c}\text { Level of } \\
\text { significance } \\
\text { Sig.*t }\end{array}$ & $\begin{array}{c}\text { Fixed } \\
\text { limit }\end{array}$ & $\begin{array}{c}\text { Hypothesis } \\
\text { Result }\end{array}$ \\
\hline $\begin{array}{l}\text { Focus on } \\
\text { operations }\end{array}$ & .312 & .097 & 3.012 & .094 & .272 & 1.73 & .094 & 2.979 & Approval \\
\hline
\end{tabular}

Table (15) shows the impact of the emphasis on operations on improving institutional performance from the point of view of managers in Jordanian government institutions. The results of the statistical analysis showed a statistically significant effect of the emphasis on operations on improving the institutional performance from the point of view of managers in the Jordanian government institutions. The correlation coefficient $\mathrm{R}(0.312)$ was at the level of $(\alpha 0.05)$. (9.7\%) of the changes in the institutional performance from the point of view of the managers in the Jordanian government institutions. The value of the effect was $\beta(0.272)$, which means that the increase of one degree in the focus on operations leads to the 
improvement of institutional performance from the point of view of managers in the Jordanian government sector institutions (0.272). The significance of this effect confirms the value of $F$, which reached (3.012), a function at the level of significance $(\alpha 00.05)$ Acceptance of the null hypothesis, which states: "There are no significant differences to focus on processes on improving institutional performance from the point of view of managers in the institutions of the Jordanian government sector at the level of

Significance (0.05).

\section{Study Conclusions}

10.1 The outcomes of the study's main research results indicate that the results were at the highest level of the "excellence in customer service" standard, and at the lowest of their average for "excellence in strategic planning".

10.2 The results of the first sub-query on institutional excellence by focusing on clients indicate that the attitudes of the decision-makers from the study sample reached the highest levels of continuous improvement in the services provided to the citizens in accordance with their changing needs at an average (high).

10.3 The results of the second sub-query on institutional excellence through leadership indicate that the attitudes of the decision-makers from the study sample came at the highest levels of providing a clear vision, mission and goals from the president to subordinates and at the lowest levels towards applying the principle of.

10.4 The results of the third sub-inquiry on institutional excellence through measurement, analysis and knowledge management indicate that the attitudes of the decision-makers from the study sample reached the highest level in encouraging the continuous learning of subordinates in the department and activating knowledge management and awareness among employees.

10.5 The results of the fourth sub-query on institutional excellence by focusing on human resources indicate that the attitudes of the decision-makers from the study sample reached the highest level with the idea that the institution was found to grow and continue to excel. The outcomes of these results indicate that the continuity of the work comes in the continuity of the institution and that the career progression represents a threat to push the seniority of the decision makers to retire according to the regulations and instructions in force.

10.6 The results of the fifth sub-query on institutional excellence by focusing on operations indicate that the attitudes of the decision-makers from the study sample reached the highest levels in order to continue the evaluation process and return it to reach the best results in providing the service and seeking research and development to identify the orientations and desires of the beneficiaries Of citizens, and at the lowest level in developing corrective plans to overcome errors resulting from misjudgment. Such results are attributed to the fact that determining the trends of beneficiaries of services is one of the most important pillars for achieving the satisfaction of the recipients. The ability to use corrective plans is difficult because the activities and the institutional plan are directly linked to the financial budget and allocations. 
10.7 The results of the sixth sub-examination on institutional excellence through strategic planning indicate that the attitudes of the decision-makers from the study sample reached the highest levels towards seeking the investment of distinctive capacities and at the lowest levels towards the development and development of human capital by empowering the workers and forming a difference Work and prepare and prepare future leaders. Such results may be attributed to the fact that the basis of excellence is the optimal investment of resources and that the work to prepare future leaders requires a lot of resources and allocations.

10.8 The results of the study hypotheses indicate that there are no statistically significant differences at the level of significance in the impact of the standards of institutional excellence and its six criteria namely: leadership, strategic planning, customer focus, measurement, analysis and knowledge management, focus on human resources, Operations) to improve institutional performance from the point of view of managers in Jordanian government sector institutions.

\section{Recommendations}

11.1 Focus on excellence in strategic planning, which contributes to the development of solutions and alternatives that weaken institutional performance and reduce the level of satisfaction of recipients of service from citizens.

11.2 To seek to maximize the basis of the acquired benefit on the principle of increasing fees and evaluation through the development of flexible financial plans.

11.3 Apply the principle of decentralization and delegation of powers in the leadership to contribute to the future leaders to continue to improve the service to its recipients.

11.4 Benefiting from the experiences of other institutions and unifying positive points at the level of the public sector in the Kingdom.

\section{References}

Al nswr, A. S. (2010). The Impact of the Organization's Characteristics on Achieving Institutional Excellence: An Applied Study in the Jordanian Ministry of Higher Education and Scientific Research, Master Thesis, Middle East University, Amman, Jordan.

Al Osman, M. (2008). An Analytical Study of MA and PhD Thesis in the field of e-Learning, King Saud University, Riyadh, Saudi Arabia, 1414-1427H (Master Thesis), Department of Educational Technology, King Saud University, Riyadh, Kingdom of Saudi Arabia.

Al sudi, M. A. (2008). The Impact of the Application of the Total Quality Management Concept on Regulatory Excellence in Commercial Banks Operating in Jordan, Jordanian Journal of Business Administration, 3(4), 275-278.

Al-Dajah, F. M. (2016). The Impact of Organizational Development on Improving Institutional Performance: A Field Study by the Participating Parties in the King Abdullah II Prize for Excellence in Government Performance, and Transparency. PhD Thesis, Faculty of Economic and Commercial Sciences and Management Sciences, Abi Bakr Belqayd 
University, Tlemcen, Algeria.

Ayyubi, M. M. (2015). The Work Environment and its Impact on Achieving Institutional Excellence: An Empirical Study on Governmental Technical Colleges in Gaza Governorates, Journal of Palestine Technical College, Issue 2, Deir Al-Balah, Palestine, pp. 107-137.

Barkhuizen, E., \& Schutte, N. (2014). Creating Public Service Excellence Applying Learning Organization Methods: The Role of Strategic Leadership, Mediterranean Journal of Social Sciences, 5(4), 159-165.

Buqais., E. (2018), the impact of knowledge management on achieving institutional excellence: the case of general coordinator of the governorates in the kingdom of Bahrain, International Journal Of Data Mining \& Knowledge Management Process (IJDKP), 4/5(8), 5-25. https://doi.org/10.5121/ijdkp.2018.8502

Gul, A. (2009). Contemporary economic and administrative issues. (1st Edition), Jordan: Arab Society Library for Publishing and Distribution.p 125.

Hijazi, N. M. (2016). Employment and its Relation to Institutional Excellence: A Field Study on Non-Governmental Organizations in the Gaza Strip (MA), Faculty of Economics and Administrative Sciences Journal, Al-Azhar University, Gaza-Palestine.

Idris, W. M., \&Al-Ghalebi, T. M. (2009). Fundamentals of Performance and Balanced Scorecard. Dar Wael Publishing \& Distribution, Amman-Jordan. P77.

Kaplan, S., \& Norton, R. (1992). The balanced scorecard measures that drive, Harvard business King Abdullah II Center for Excellence, available at: http://www.jusbp.org/arabic/king_award.shtm. htm (Feb 7, 2019)

Qawasmeh, F. M., \& Al-Burini, F. (2016). Evaluation of University Excellence Management Practices using the European Model from the Perspective of Students and Staff at Jadra University, Arab Journal of Economics and Business.Jordan.

Sahli, A. b. M. (2016). The Role of the Organization in Achieving Institutional Excellence at the Educational Supervision Offices in Riyadh: Proposed Strategy, Master Thesis, College of Education, King Saud University, Riyadh, Saudi Arabia, p 75.

\section{Copyright Disclaimer}

Copyright for this article is retained by the author(s), with first publication rights granted to the journal.

This is an open-access article distributed under the terms and conditions of the Creative Commons Attribution license (http://creativecommons.org/licenses/by/4.0/). 